\title{
Effects of some environmental factors on the population density and species diversity of phytoplankton in Bitter Lakes, Egypt
}

\author{
Mohamed Zein Alabdein Nassar ${ }^{1}$ Mamdouh Amin Fahmy ${ }^{2}$
}

Received: 1 December 2014/ Accepted: 11 September 2015/Published online: 14 October 2015

(c) The Author(s) 2015. This article is published with open access at Springerlink.com

\begin{abstract}
The assessment of the phytoplankton community structure in the Bitter Lakes during 2012-2013 indicated about 150 species belonging to 73 genera. These are classified as 89 species of diatoms, 27 dinoflagellates, 19 chlorophytes, 13 cyanophytes, and one of euglenophytes as well as one rare species of silicoflagellates. Diatoms were the leading and most dominant group forming about $81.67 \%$ of the total number of individuals due to the high flourishing of Rhizosolenia alata variety gracillima, Thalassionema nitzschioides, Skeletonema costatum, Thalassiothrix frauenfeldii, and Chaetoceros lorenzianus. AbuRommanh was the most productive area in the phytoplankton counts, whereas the area of Shandoura was the lowest productive one, coincided principally with the types and amounts of pollutants as well as the highest human and fishing activities at this area of the Bitter Lakes. Seasonally, summer 2012 was the most productive season with an average of 8464 unit/L followed by autumn 2012 with an average of 6199 unit/L. Whereas, the winter and spring of 2013 were observed with approximately similar averages of 5527 and 5194 unit/L, respectively. Analysis of diversity indicated that the Bitter Lakes sustained good variations of phytoplankton species. It fluctuated between the averages of 2.4 in the spring of 2013 and 3.21 during the autumn of 2012, which may reflect the healthy state and
\end{abstract}

Mohamed Zein Alabdein Nassar

mnassar65@yahoo.com

Mamdouh Amin Fahmy

mamfahmy@gmail.com

1 National Institute of Oceanography and Fisheries, B.O. 182, Suez, Egypt

2 National Institute of Oceanography and Fisheries, Alexandria, Egypt ecosystem stability of Bitter Lakes during autumn. The results revealed that the total density of phytoplankton slightly increased from the average counts of 6286 unit/L during 2002-2003 to 6346 unit/L in the present study, while the number of species significantly increased from 108 species in 2002-2003 to 150 species in the present study. This may be due to the relative increase in the eutrophication state of the Bitter Lakes during the last 10 years. Generally, the seasonal fluctuations of phytoplankton positively correlated with the water temperature $\left(22-24.2^{\circ} \mathrm{C}\right)$, dissolved oxygen $(4.85-11.11 \mathrm{mg} / \mathrm{L})$, and reactive nitrate $(0.04-1.00 \mathrm{mg} / \mathrm{L})$, but it inversely correlated with the ammonium $(0.05-0.2 \mathrm{mg} / \mathrm{L})$ and reactive silicate $(0.10-1.44 \mathrm{mg} / \mathrm{L})$. The stepwise multiple regressions indicated that the reactive silicate, nitrate, and ammonium were the most effective factors that controlled the seasonal fluctuations and species diversity of phytoplankton in the Bitter Lakes during 2012-2013.

Keywords Phytoplankton - Diversity · Nutrients - Bitter Lakes · Egypt

\section{Introduction}

Bitter Lakes $\left(30^{\circ} 20^{\prime} \mathrm{N}, 32^{\circ} 23^{\prime} \mathrm{E}\right)$ are the largest water bodies along the length of the Suez Canal, containing about $85 \%$ of the system's water. The Great and Small Bitter Lakes are separated by a narrow and saline connection situated between the North and South parts of the Suez Canal (Fig. 1). Together, they have a surface area of about $250 \mathrm{~km}^{2}$. To the North, the canal also runs through Lakes Manzala and Temsah. As the canal has no locks, sea water flows freely into the lakes from both the Mediterranean and Red Seas. The lakes act as a buffer for the canal, reducing 


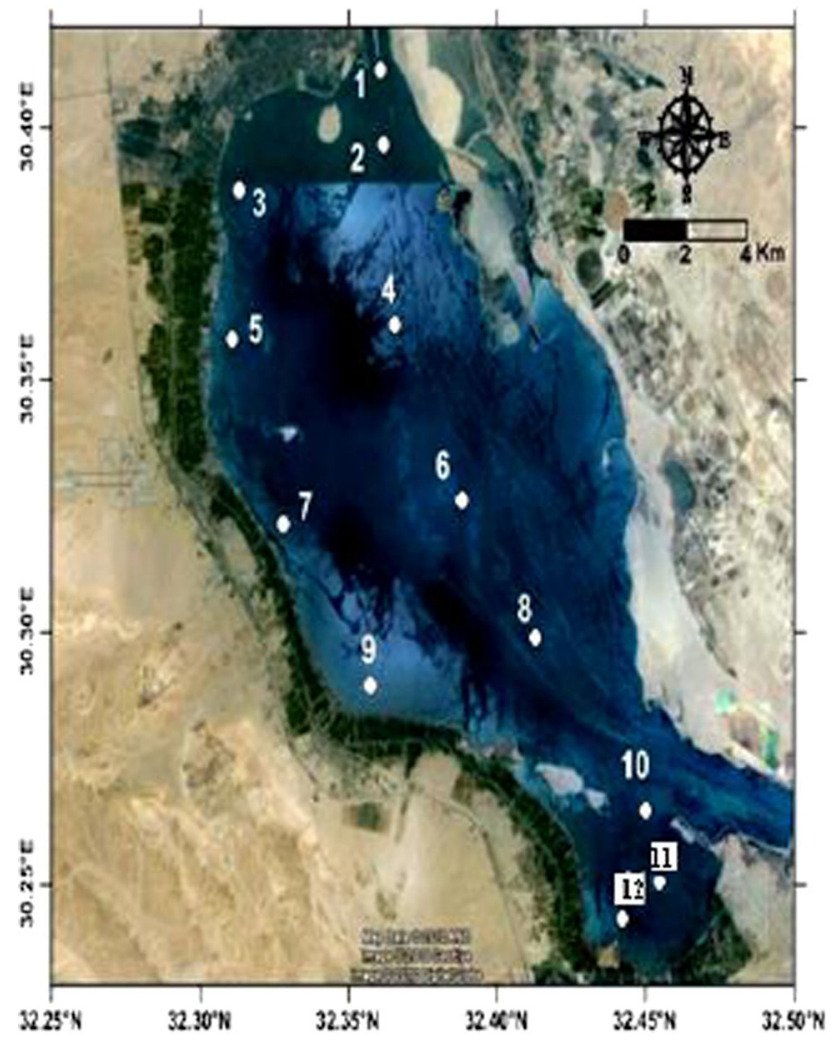

Fig. 1 Positions of the sampling stations of Bitter Lakes

the effect of tidal currents (Touliabah and Taylor 2004). The Bitter Lakes suffer from various types of pollution, including domestic sewage from the surrounding human settlements and thermal pollution from Abu-Sultan electric power station's cooling water, as well as industrial and agricultural wastes from Ismailia City via the Malaria Drain, which also collects agricultural drainage from the cultivated lands on the west bank of the Great Bitter Lake. Generally, the tourist villages and agricultural land surrounding the lake boundaries affect the water quality of the lake due to drainage discharge along the western lakes' side (Madkour 1992; GADFR 2007). The eutrophication state of the Bitter Lakes was recently investigated by Hamed et al. (2012).

Several authors studied the phytoplankton distribution in some regions of the Suez Canal like Dowidar (1971, 1976), Dorgham and Dowidar (1983), Dorgham (1985, 1990), ElSherif and Ibrahim (1993), and Madkour (2000). Touliabah and Taylor (2004) examined the impact of sewage and agricultural wastes as well as the heated effluents from Abu-Sultan electric power station on the phytoplankton community of the lakes. They concluded that the phytoplankton abundance and species composition in the Bitter Lakes are more closely related to temporal and seasonal variations of the environmental parameters than to point sources of pollution. Nassar and Shams El-Din (2006) indicated that a total of 116 taxa were identified in the Bitter Lakes and Temsah Lake of the Suez Canal, among which are 72 taxa of diatoms, 16 dinoflagellates, 14 chlorophytes, 11 cyanophytes, two euglenophytes, and one silicoflagellate species. Madkour (2007) examined the population density of phytoplankton in the Suez Canal and recorded a total of 204 species and varieties. He reported that the phytoplankton organisms were belonging to seven classes, namely Bacillariophyceae (97 species), Dinophyceae (59 species), Chlorophyceae (23 species), Cyanophyceae (17 species), Euglenophyceae (five species), Cryptophyceae (two species), and one species of silicoflagellates.

\section{Materials and methods}

Estimation of the phytoplankton was carried out by filtration of about $100 \mathrm{~L}$ of the surface water samples by the plankton net of $20 \mu \mathrm{m}$ mesh size, for qualitative studies, as well as collection of five liters of water samples for the quantitative studies at twelve different stations of the Bitter Lakes during the summer and autumn of 2012 and the winter and spring of 2013. The samples were preserved immediately in $4 \%$ neutralized formalin. In the laboratory, the sedimentation technique of the samples was carried out according to Utermöhl (1958); then sub samples of $1 \mathrm{~mL}$ were transferred into Sedgewick Rafter counting cell for identification and counting under the inverted research microscope. The water temperature was measured using a simple pocket thermometer graduated to $0.1{ }^{\circ} \mathrm{C}$. The $\mathrm{pH}$ value of the water samples was measured in situ using a pocket $\mathrm{pH}$ meter model Orion 210. Dissolved oxygen determination was carried out according to APHA (1995). Nutrient salts $\left(\mathrm{NO}_{3}, \mathrm{NH}_{4}, \mathrm{PO}_{4}\right.$, and $\left.\mathrm{SiO}_{4}\right)$ were determined spectrophotometrically according to the methods described by Strickland and Parsons (1968).

\subsection{Description of the sampling stations}

Twelve ecologically different stations were selected covering most of the area of Bitter Lakes (Fig. 1). These sites can be described as follows: St.1 (Defresoir) is located near the navigation channel of the Suez Canal and it is far from the pollution sources with about $15 \mathrm{~m}$ depth; St.2 (AbuSultan offshore) is situated in front of the Electric Power Station of Abu-Sultan with about 13 m depth; St.3 (AbuSultan inshore) is also near the Electric Power Station with about $2.5 \mathrm{~m}$ depth; St.4 (Fayed offshore) is near from the navigation channel of the Suez canal with about $12.5 \mathrm{~m}$ depth; St.5 (Fayed inshore) is subjecting to some pollutants as a result of the tourist activities at Fayed City with about $2 \mathrm{~m}$ depth; St.6 (Fanara offshore) is near from the 
navigation channel of the canal with about $13 \mathrm{~m}$ depth; St.7 (Fanara inshore) is near from the drain of Fanara City with about $2.5 \mathrm{~m}$ depth; St.8 (Abu-Rommanh offshore) is near from the navigation channel of the Suez Canal with about $14 \mathrm{~m}$ depth; St.9 (Abu-Rommanh inshore) is subjecting to some pollutants from the drain of Abu-Rommanh City with about $3 \mathrm{~m}$ depth; St.10 (Kabreit offshore) is located in front of the Kabreit City with about $3 \mathrm{~m}$ depth; and the stations 11 and 12 are locating in the offshore and the inshore sites of Shandoura. This area is subjecting to sewage impacts as well as the prevailing ecological factors including high human and fishing activities.

\subsection{Statistical analysis}

The species diversity of phytoplankton was calculated according to the equations of Shannon and Wiener (1963), and the correlation matrices and the stepwise multiple regressions of the data were carried out on the computer using the PRIMER Statistical program version 5.

\section{Results and discussion}

\subsection{Physico-chemical parameters}

\subsubsection{Temperature}

Temperature is a limiting factor in the aquatic characteristic of the compound. It affects water quality in terms of the chemical, metabolic activities, growth, feeding, reproduction, and physical and biological contents of water (Crillet and Quetin 2006). The water distribution and migratory behaviors of aquatic quality of rivers and lakes change with the seasons and organisms. It affects the solubility of gasses in water and geographic areas; even when there is no pollution, gas solubility decreases with increasing temperature (Suski et al. 2006). In the present study, the mean water temperature in the Bitter Lakes was found to be between $22{ }^{\circ} \mathrm{C}$ in the coastal water of Shandoura (St.12) and $24.2{ }^{\circ} \mathrm{C}$ at the offshore water of AbuRommanh (St.9), with an annual mean of $23.43{ }^{\circ} \mathrm{C}$ (Table 1).

\subsection{2 $\mathrm{pH}$ value}

Hydrogen ion concentration or $\mathrm{pH}$ is one of the vital environmental characteristics, which decides the survival metabolism, physiology, and growth of aquatic organisms (Ramanathan et al. 2005). The principal components regulating ion $\mathrm{pH}$ in natural water are the carbonates, which comprise $\mathrm{CO}_{2}$ and $\mathrm{H}_{2} \mathrm{CO}_{3}$ (APHA 2006). During the present study, the $\mathrm{pH}$ varied in the Bitter Lakes between the mean value of 7.81 in the inshore water of Fayed (St.5) and 8.49 in the offshore water of Fayed (St.4), with an annual mean of 8.21.

\subsubsection{Dissolved oxygen}

Dissolved oxygen affects the solubility and availability of nutrients. Its low levels can result in damage to the oxidation state of substances from the oxidized to the reduced form, thereby increasing the levels of toxic metabolites. Dissolved carbon dioxide in aquatic environment increases with decreasing dissolved oxygen. It is an important parameter in primary production and phytoplankton biomass (Lawson 2011). The present concentrations of DO in the Bitter Lakes fluctuated between the mean values of $4.85 \mathrm{mg} / \mathrm{L}$ at St.12 and $11.11 \mathrm{mg} / \mathrm{L}$ at St.9, with an annual mean of $7.58 \mathrm{mg} / \mathrm{L}$. The highest mean value of DO in the spring of $2013(8.87 \mathrm{mg} / \mathrm{L})$ was associated with the high occurrence of the dominant diatom; Rhizosolenia alata variety gracillima represents about $40.74 \%$ of the total diatoms in the spring with an average count of 1660 cell/L.

\subsection{Nutrient salts}

Nitrate and ammonium are the main nitrogen forms associated with human influence. Nitrate derives from the land clearing, production, and applications of fertilizers, while ammonium derives from the human waste discharge (Domingues and Barbosa 2011). In the present study, the levels and mean values of nitrate, reactive phosphate, ammonium, and reactive silicate are shown in Table 1.

\subsubsection{Nitrate}

The maximum concentrations of nitrate were recorded in the coastal water of Abu-Rommanh (St.9) with a mean of $1.0 \mathrm{mg} / \mathrm{L}$, while the minimum mean value of $0.04 \mathrm{mg} / \mathrm{L}$ was found in the coastal water of Shandoura, which sustained the lowest abundance of phytoplankton with a total count of 3453 unit/L (Figs. 2, 3, 4, 5). Generally, the relatively high values of nitrate, i.e., a mean of $0.521 \mathrm{mg} / \mathrm{L}$, were found in the summer of 2012 that sustained the highest flourishing of phytoplankton, whereas the lowest annual mean value of $0.067 \mathrm{mg} / \mathrm{L}$ was obtained in the spring of 2013.

\subsubsection{Ammonium}

Ammonium $\left(\mathrm{NH}_{4}{ }^{+}\right)$represented $80 \%$ of the total dissolved inorganic nitrogen, and its highest values were always associated with freshwater inflow (George et al. 2012). According to Suthers and Rissik (2009) and Taofikat Adesalu (2012), the major limiting nutrients for 
Table 1 The mean concentrations of some physico-chemical parameters in the Bitter Lakes during 2012-2013

\begin{tabular}{|c|c|c|c|c|c|c|c|}
\hline & Temp $\left({ }^{\circ} \mathrm{C}\right)$ & $\mathrm{pH}$ & DO (mg/L) & $\mathrm{PO}_{4}(\mu \mathrm{g} / \mathrm{L})$ & $\mathrm{NH}_{3}(\mathrm{mg} / \mathrm{L})$ & $\mathrm{NH}_{4}(\mathrm{mg} / \mathrm{L})$ & $\mathrm{SiO}_{4}(\mathrm{mg} / \mathrm{L})$ \\
\hline \multicolumn{8}{|l|}{ Stations } \\
\hline 1 & 23.13 & 8.20 & 7.97 & 22.46 & 0.510 & 0.100 & 0.155 \\
\hline 2 & 23.20 & 8.15 & 8.40 & 21.77 & 0.610 & 0.086 & 0.123 \\
\hline 3 & 23.80 & 8.18 & 7.56 & 22.15 & 0.217 & 0.130 & 0.255 \\
\hline 4 & 23.70 & 8.49 & 7.23 & 23.69 & 0.157 & 0.116 & 0.315 \\
\hline 5 & 23.50 & 7.81 & 7.10 & 23.80 & 0.157 & 0.126 & 0.400 \\
\hline 6 & 23.70 & 8.07 & 8.87 & 22.16 & 0.70 & 0.080 & 0.119 \\
\hline 7 & 23.60 & 8.21 & 7.36 & 23.36 & 0.197 & 0.116 & 0.285 \\
\hline 8 & 23.80 & 8.26 & 7.84 & 23.00 & 0.410 & 0.110 & 0.200 \\
\hline 9 & 24.20 & 8.29 & 11.11 & 16.49 & 1.00 & 0.050 & 0.100 \\
\hline 10 & 23.90 & 8.17 & 6.66 & 26.77 & 0.117 & 0.136 & 0.500 \\
\hline 11 & 22.60 & 8.32 & 6.06 & 190.93 & 0.047 & 0.171 & 1.44 \\
\hline 12 & 22.00 & 8.36 & 4.85 & 27.47 & 0.040 & 0.200 & 0.600 \\
\hline \multicolumn{8}{|l|}{ Seasons } \\
\hline Summer (2012) & 28.16 & 8.38 & 6.57 & 40.76 & 0.521 & 0.097 & 0.358 \\
\hline Autumn (2012) & 22.33 & 7.76 & 6.15 & 35.00 & 0.64 & 0.102 & 0.628 \\
\hline Winter (2013) & 18.23 & 8.27 & 8.73 & 34.97 & 0.141 & 0.227 & 0.050 \\
\hline Spring (2013) & 25.01 & 8.41 & 8.87 & 20.65 & 0.067 & 0.047 & 0.468 \\
\hline Annual mean & 23.43 & 8.21 & 7.58 & 32.83 & 0.342 & 0.118 & 0.376 \\
\hline
\end{tabular}

Fig. 2 Phytoplankton abundance in the Bitter Lakes during summer, (2012)

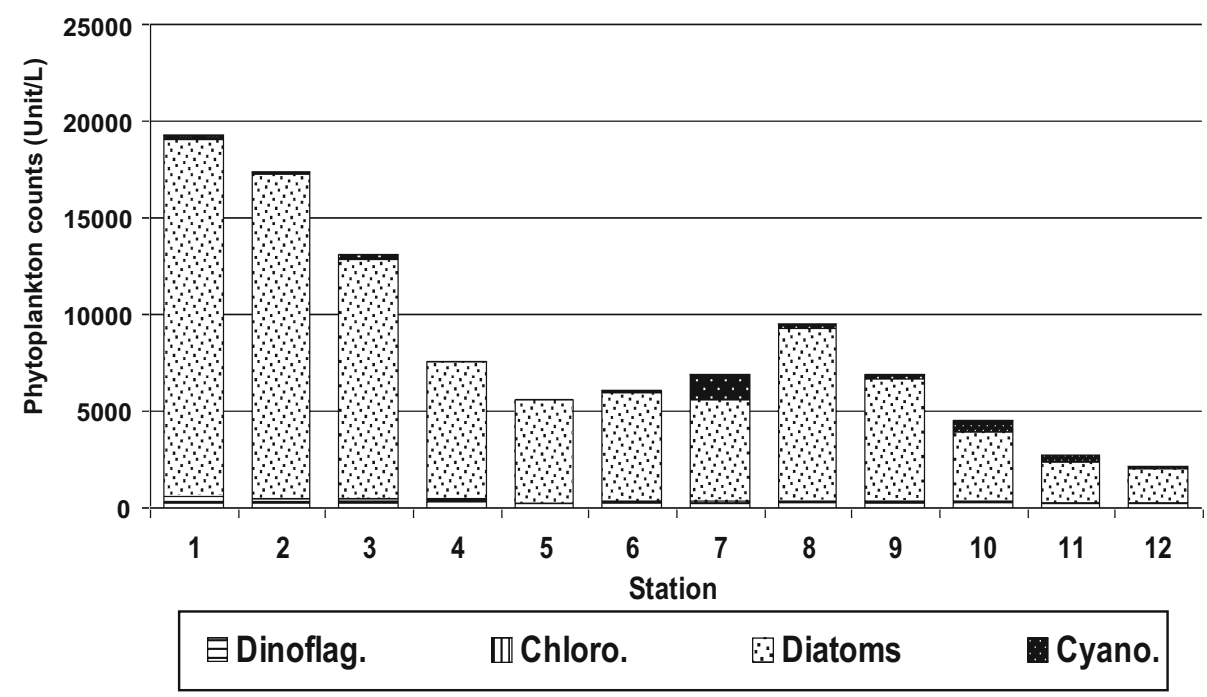

phytoplankton are nitrogen in the form of ammonium $\left(\mathrm{NH}_{4}{ }^{+}\right)$, nitrite $\left(\mathrm{NO}_{2}{ }^{-}\right)$, and phosphate $\left(\mathrm{PO}_{4}{ }^{-}\right)$. Nitrogen tends to be the limiting nutrient in marine systems, while phosphate is the limiting nutrient in the freshwater systems. These two nutrients are needed for cell membranes and for proteins such as enzymes. Generally, Adesalu and Nwankwo (2010) identified phytoplankton as one of the useful indicators of aquatic environmental quality because they act as early warning signals, thereby provoking appropriate remediation. They reported that high ammonium compound and low reactive nitrogen promoted the increase of Anabaena and Nostoc of Cyanobacteria. In this study, the dissolved ammonium in the Bitter Lakes varied within a narrow limit $(0.05 \mathrm{mg} / \mathrm{L}$ at $\mathrm{St} .9-0.20 \mathrm{mg} / \mathrm{L}$ at St.12) with an annual mean of $0.118 \mathrm{mg} / \mathrm{L}$. However, Hamed et al. (2012) indicated that ammonium concentrations in the Bitter Lakes fluctuated between 0.19 and $5.76 \mu \mathrm{mol} / \mathrm{L}$. 
Fig. 3 Phytoplankton abundance in the Bitter Lakes during autumn, (2012)

Fig. 4 Phytoplankton abundance in the Bitter Lakes during winter, (2013)
Fig. 5 Phytoplankton abundance in the Bitter Lakes during spring, (2013)

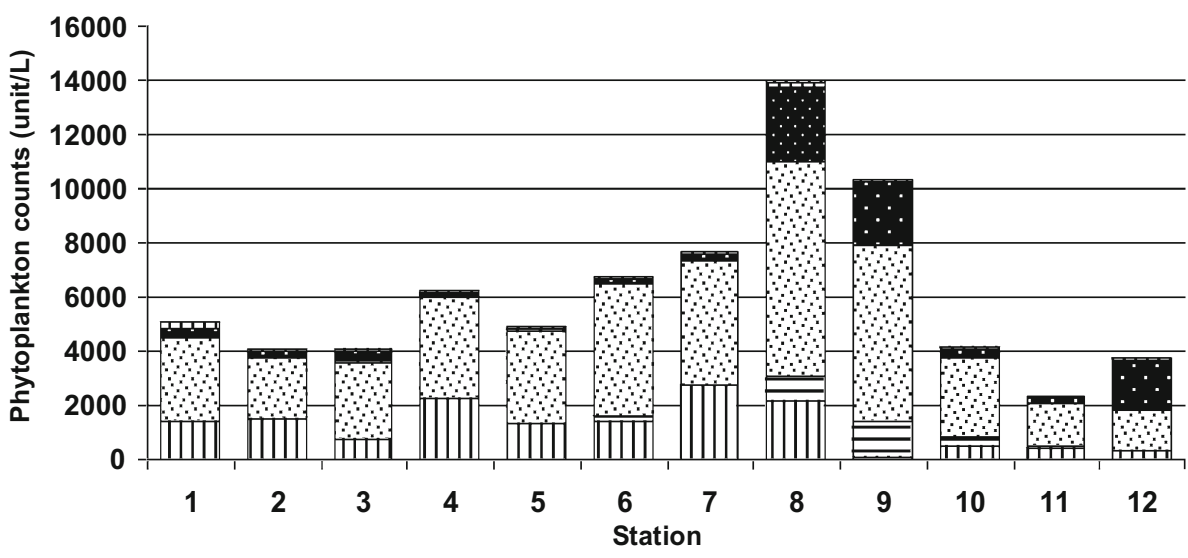

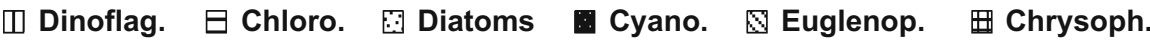
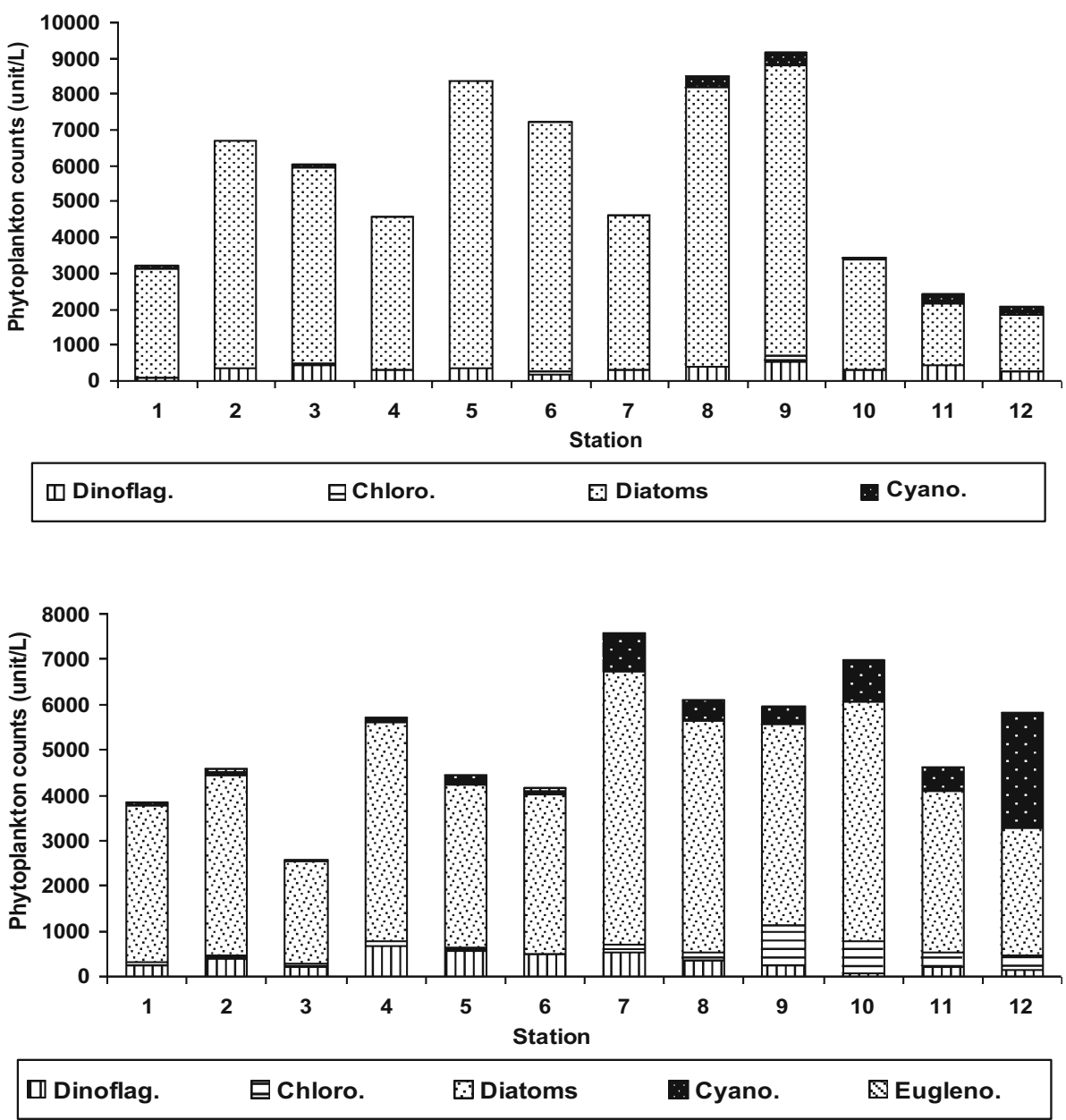

\subsubsection{Reactive phosphate}

In marine environment, the concentration of phosphate is always low particularly at the surface waters. The phosphate is readily utilized by the primary producers and, when increased levels result in algal growth, causes severe bloom (Saravanakumar et al. 2008). Minimum mean value of $16.49 \mu \mathrm{g} / \mathrm{L}$ phosphate was observed in the inshore water of Abu-Rommanh (St.9), and the maximum one was recorded at about $190.93 \mu \mathrm{g} / \mathrm{L}$ in the offshore water of Shandoura (St.11), with an annual mean of $32.83 \mu \mathrm{g} / \mathrm{L}$. In general, almost all the obtained phosphate values may be 
Table 2 Seasonal variations of the phytoplankton (average of 12 stations) in the Bitter Lakes during 2012-2013

\begin{tabular}{|c|c|c|c|c|c|c|}
\hline \multirow[t]{2}{*}{ Algal group } & \multicolumn{2}{|l|}{2012} & \multicolumn{2}{|l|}{2013} & \multirow[t]{2}{*}{ Average } & \multirow[t]{2}{*}{ Freq. (\%) } \\
\hline & Summer & Autumn & Winter & Spring & & \\
\hline Diatoms & 7820 & 3770 & 5067 & 4074 & 5183 & 81.67 \\
\hline Dinoflagellates & 356 & 1321 & 321 & 346 & 586 & 9.23 \\
\hline Cyanophytes & 269 & 777 & 109 & 521 & 419 & 6.60 \\
\hline Chlorophytes & 19 & 235 & 30 & 243 & 132 & 2.1 \\
\hline Euglenophytes & 0.0 & 33 & 0.0 & 10 & 11 & 0.17 \\
\hline Silicoflagellates & 0.0 & 63 & 0.0 & 0.0 & 16 & 0.25 \\
\hline Total abundance & 8464 & 6199 & 5527 & 5194 & 6346 & 100 \\
\hline No. of species & 55 & 87 & 53 & 58 & - & - \\
\hline Species diversity & 2.795 & 3.209 & 2.763 & 2.375 & 2.785 & - \\
\hline
\end{tabular}

due to the sewage, agriculture discharge, and the fishing activities at the area of Shandoura as well as the high turbulence and mixing of the water column resulting in the regeneration of total phosphate at this area of the Bitter Lakes.

\subsubsection{Reactive silicate}

The reactive silicate concentrations in the surface water of the Bitter Lakes ranged from the maximum mean value of $0.1 \mathrm{mg} / \mathrm{L}$ in the inshore water of Abu-Rommanh to $1.44 \mathrm{mg} / \mathrm{L}$ in the offshore water of Shandoura, with an annual mean of $0.376 \mathrm{mg} / \mathrm{L}$. Generally, the low concentrations of reactive silicate at the area of Abu-Rommanh are principally due to its consumption by the flourishing diatoms especially during the most productive season, i.e., summer of 2012 (average of 7820 cell/L), as presented in Table 2.

\section{Phytoplankton distribution}

\subsection{Community composition}

The present results indicated about 150 species belonging to 73 genera of phytoplankton in the Bitter Lakes during 2012-2013. These species are classified as 89 species of diatoms, 27 of dinoflagellates, 19 chlorophytes, 13 cyanophytes, and one of euglenophytes as well as one rare species of silicoflagellates.

Diatoms were the leading and most dominant group forming about $81.67 \%$ of the total counts of phytoplankton with an average of 5183 cell/L. This was associated with the high flourishing of the leading one, Rhizosolenia alata variety gracillima (Cleve) Grunow ex Van Heurck (average of 986 cell/L), followed by Thalassionema nitzschioides (Grunow) Mereschkowsky (average of 644 cell/ L), Skeletonema costatum (Greville) Cleve (average of 565
cell/L), Thalassiothrix frauenfeldii (Grunow) (average of 478 cell/L), and Chaetoceros lorenzianus (Grunow) (average of $428 \mathrm{cell} / \mathrm{L}$ ). The dinoflagellates formed about $9.23 \%$ of the total density of phytoplankton with average counts of 586 cell/L. This accompanied with the relatively high occurrence of Ceratium furca (Ehrenberg) Claparède \& Lachmann (average of $221 \mathrm{cell} / \mathrm{L}$ ). On the other hand, the other algal groups were observed with low to moderate counts forming collectively about $9.1 \%$ of the total counts of the phytoplankton with relatively high occurrence of Chroococcus minutus (Kützing) Nägeli (average of 186 unit/L) of cyanophytes. However, some freshwater forms of cyanophytes and euglenophytes were observed in the present study as a result of sewage and freshwater effluents that are discharged into some sites of the Bitter Lakes.

Generally, the Station 8 (Abu-Rommanh offshore) followed by St.9 (Abu-Rommanh inshore) and St.2 (AbuSultan offshore) were the most productive and fertile sites with total counts of 9507,8315 , and 8196 unit/L, respectively. Whereas, at station 11 (Shandoura offshore) and Station 12 (Shandoura inshore), the lowest population density was found with total counts of 3453 and 3041 unit/ $\mathrm{L}$, respectively. This may be due to that they are subjecting to different types of pollutants as well as the high human and fishing activities.

\subsection{Seasonal variations}

Summer of 2012 was the most productive season in the Bitter Lakes with an average of 8464 unit/L. This was accompanied with the high flourishing of some dominant diatoms, especially Thalassionema nitzschioides (total counts of 1348 cell/L), Thalassiothrix frauenfeldii (total counts of 1348 cell/L), Chaetoceros lorenzianus (1062 cell/L), Chaetoceros didymus Ehrenberg (500 cell/ L), and Rhizosolenia alata variety gracillima (500 cell/L). The autumn of 2012 was the second productive season in 
Table 3 The number of species and total abundance of phytoplankton in the Bitter Lakes during 2002-2003 and 2012-2013

\begin{tabular}{|c|c|c|c|c|c|c|c|c|}
\hline \multirow[t]{2}{*}{ Algal group } & \multicolumn{4}{|c|}{ Bitter Lakes (2002-2003) Nassar and Shams El-Din (2006) } & \multicolumn{4}{|c|}{ Bitter Lakes (2012-2013) (present study) } \\
\hline & Genus & Species & Total counts (unit/L) & $\%$ & Genus & Species & Total counts (unit/L) & $(\%)$ \\
\hline Diatoms & 35 & 68 & 4725 & 75.16 & 39 & 89 & 5183 & 81.67 \\
\hline Dinoflagellates & 9 & 15 & 955 & 15.20 & 12 & 27 & 586 & 9.23 \\
\hline Chlorophytes & 8 & 11 & 230 & 3.66 & 12 & 19 & 132 & 2.10 \\
\hline Cyanophytes & 7 & 11 & 330 & 5.25 & 8 & 13 & 419 & 6.60 \\
\hline Euglenophytes & 2 & 2 & 34 & 0.54 & 1 & 1 & 11 & 0.17 \\
\hline Silicoflagellates & 1 & 1 & 12 & 0.19 & 1 & 1 & 16 & 0.25 \\
\hline Total & 62 & 108 & 6286 & 100 & 73 & 150 & 6346 & 100 \\
\hline
\end{tabular}

the Bitter Lakes with total counts of 6199 unit/L, which coincided with high flourishing of the diatom, Skeletonema costatum (total counts of 690 cell/L) as well as Chroococcus minutus of cyanophytes (counts of 433 unit/ L). Whereas, the winter and spring of 2013 were recorded with approximately similar counts of 5527 and 5194 unit/ L, respectively (Figs. 2, 3, 4, 5). Generally, the total numbers of the recorded species in the Bitter Lakes were $55,87,53$, and 58 species during summer, autumn, winter, and spring, respectively (Table 2 ).

In conclusion, comparing the results of the present study with those reported during 2002-2003 by Nassar and Shams El-Din (2006), the obtained results revealed that the total density of the phytoplankton is slightly increased from the average counts of 6286 unit/L during 2002-2003 to 6346 unit/L in the present study, while the number of species is significantly increased from 108 species in 2002-2003 to 150 species in the present study as shown in Table 3 . This may be accompanied with the relatively high eutrophication state of the Bitter Lakes during the last 10 years (Hamed et al. 2012).

However, the tourist villages and agricultural lands surrounding the lakes' boundaries affected the water quality of the Bitter Lakes due to the drainage and agriculture discharge as well as the high human and fishing activities along the western lakes' side especially at Shandoura and Fayed areas. Thus, these types of pollutants could be reduced and treated as much as possible before discharging into the waters of Bitter lakes.

\subsection{Species diversity}

Diversity of planktonic organisms is quite high in fertile standing water bodies. Phytoplankton diversity responds rapidly to changes in the aquatic environment particularly in relation to silica and other nutrients (Mukherjee et al. 2010). Several phytoplankton species have served as bioindicators and are a well-suited tool for understanding water pollution studies (Rajagopal et al. 2010). In the present study, analysis of diversity using the program of Primer version 5 indicated that the Bitter Lakes sustained good variations of phytoplankton species. The highest value of 3.562 was recorded during the autumn of 2012 in the offshore water of Fayed (St.4), which is relatively far from the pollution sources. While, the lowest value of 1.641 was found during the spring of 2013 at the inshore water of the same site, near which the high human and tourist activities are found. Generally, the highest mean value of 3.209 was observed during autumn 2012 that achieved the highest numbers of species ( 87 species) as compared with the mean values $2.375,2.763$, and 2.795 during spring ( 58 species), winter ( 53 species), and summer (55 species), respectively (Table 2 ). This may reflect the relatively healthy state and stability of ecosystem in Bitter Lakes during autumn than other seasons of the study period.

\section{Statistical analysis}

The correlation matrices of the present data (Table 4) revealed that the seasonal fluctuations of phytoplankton in the Bitter Lakes during 2012-2013 positively correlated with the water temperature $(r=0.63)$, dissolved oxygen $(r=0.93)$, and the reactive nitrate $(r=0.92)$, but it inversely correlated with ammonium $(r=-0.96)$ and the reactive silicate $(r=-0.83)$.

The stepwise multiple regressions indicated that the reactive silicate, nitrate, and ammonium were the most effective factors that controlled the seasonal fluctuations and species diversity of phytoplankton during 2012-2013. The regression analysis indicated that phytoplankton counts $=8316.1+0.311 \quad \mathrm{NO}_{3}+0.395 \quad \mathrm{PO}_{4}-0.78$ $\mathrm{SiO}_{4}-0.3 \mathrm{NH}_{4}$ (M.R. $=0.995$; beta values are significant at $p<0.0001$ and $N=12$ ). This equation could be applied in the future to predict the relationship between the nutrients and total phytoplankton counts in the Bitter Lakes of Suez Canal, Egypt. 
Table 4 The correlations between some physico-chemical parameters and the total counts of phytoplankton (bold correlations are significant at $p<0.05, N=12$ )

\begin{tabular}{lrrrrrrrr}
\hline & \multicolumn{1}{c}{$\mathrm{Temp}$} & \multicolumn{1}{c}{$\mathrm{pH}$} & \multicolumn{1}{c}{$\mathrm{DO}$} & \multicolumn{1}{c}{$\mathrm{PO}_{4}$} & \multicolumn{1}{c}{$\mathrm{NO}_{3}$} & $\mathrm{NH}_{4}$ & $\mathrm{SiO}_{4}$ & Phyto. \\
\hline $\mathrm{Temp}$ & 1.00 & & & & & & & \\
$\mathrm{pH}$ & -0.2 & 1.00 & & & & & & \\
$\mathrm{DO}$ & $\mathbf{0 . 7 1}$ & -0.14 & 1.00 & & & & & \\
$\mathrm{PO}_{4}$ & -0.45 & 0.20 & -0.36 & 1.00 & & & & \\
$\mathrm{NO}_{3}$ & 0.47 & -0.10 & $\mathbf{0 . 9 3}$ & -0.36 & 1.00 & & & \\
$\mathrm{NH}_{4}$ & $\mathbf{- 0 . 7 5}$ & 0.20 & $\mathbf{- 0 . 9 6}$ & 0.46 & $\mathbf{- 0 . 8 9}$ & 1.00 & & \\
$\mathrm{SiO}_{4}$ & $\mathbf{- 0 . 5 8}$ & 0.21 & $\mathbf{- 0 . 6 3}$ & $\mathbf{0 . 9 2}$ & $\mathbf{- 0 . 6 2}$ & $\mathbf{0 . 7 3}$ & 1.00 & \\
Phyto. & $\mathbf{0 . 6 3}$ & -0.21 & $\mathbf{0 . 9 3}$ & -0.58 & $\mathbf{0 . 9 2}$ & $\mathbf{- 0 . 9 6}$ & $\mathbf{- 0 . 8 3}$ & 1.00 \\
\hline
\end{tabular}

Open Access This article is distributed under the terms of the Creative Commons Attribution 4.0 International License (http://creati vecommons.org/licenses/by/4.0/), which permits unrestricted use, distribution, and reproduction in any medium, provided you give appropriate credit to the original author(s) and the source, provide a link to the Creative Commons license, and indicate if changes were made.

\section{References}

Adesalu TA, Nwankwo DI (2010) A checklist of desmids of Lekki lagoon, Nigeria. Int J Biodivers Conserv 2(3):33-36

APHA (American public Health Association) (1995) Standard methods for the examination of water and wastewater, 19th edn. American public Health Association, New York, p 1015

APHA (2006) Standard methods for the examination of water and wastewater, 21st edn. APHA, Washington, DC

Crillet C, Quetin P (2006) Effect of temperature changes on the reproductive cycle of loach in Lake Geneva from 1983 to 2001. J Fish Biol 69:518-534

Domingues RB, Barbosa AB (2011) Ammonium, nitrate and phytoplankton interactions in a freshwater tidal estuarine zone: potential effects of cultural eutrophication. Aquat Sci 73:331-343

Dorgham MM (1985) Distribution of phytoplankton in spring along the Suez Canal. Rapp Comm Int Mer Medit 29:123-124

Dorgham MM (1990) Studies on the phytoplankton of the northern end of Suez Canal (January 1990). Egypt J Appl Sci 5(8):90-95

Dorgham MM, Dowidar NM (1983) Seasonal and spatial biometric variations in Rhizosolenia shrubsolei from 3 areas in the Suez Canal Rapp. Comm Int Mer Medit 28(9):101-103

Dowidar NM (1971) The distribution and ecology of Ceratium egyptiacum Halim and its validity as indicator of the current regime in the Suez Canal. Int Revue der gesamten Hydrobiol und Hydrogr 56(6):957-966

Dowidar NM (1976) The phytoplankton of the Suez Canal Symp. East. Med. Sea. IBP/PM UNESCO. Acta Adriat 18(14):241-255

El-Sherif ZM, Ibrahim AM (1993) Phytoplankton production, diversity and chlorophyll-a in Suez Canal. Egypt Bull Nat Inst Oceanogr Fish A.R.E 19:191-212

GADFR (2007) General Authority for Development of Fisheries Resources. Fisheries reports (monthly and annual yield, fishing vessels and gears and number of involved fishermen)

George B, Nirmal KJI, Kumar RN (2012) Study on the influence of hydro-chemical parameters on phytoplankton distribution along Tapi estuarine area of Gulf of Khambhat, India. Egypt J Aquat Res 38(3):157-170

Hamed MA, El-Sawy MA, Abu El-Naga EH (2012) Hydrochemistry and nutrients of Bitter and Temsah Lakes Suez Canal Egypt. Egypt J Aquat Biol Fish 16(2):1-12 (ISSN 1110-1131)
Lawson OE (2011) Physico-chemical parameters and heavy metal contents of water from the Mangrove Swamps of Lagos Lagoon, Lagos, Nigeria. Adv Biol Res 5(1):8-21

Madkour F (1992) Ecological studies on the phytoplankton of the Bitter Lakes. M.Sc. thesis, Faculty of science, Suez Canal University, Egypt, p 155

Madkour FT (2000) Ecological studies of the phytoplankton of the Suez Canal Ph.D. thesis, University of Suez Canal, Faculty of Science, Egypt, pp 154

Madkour FT (2007) The potential impact of Lake Manzala on the phytoplankton and hydrographic characters of the Suez Canal, Egypt. Egypt J Aqua Biol Fish 77(2):185-204

Mukherjee B, Nivedita M, Mukherjee D (2010) Plankton diversity and dynamics in a polluted eutrophic lake, Ranchi. J Environ Biol 31(5):827-839

Nassar MZ, Shams El-Din NG (2006) Seasonal dynamics of phytoplankton community in Bitter Lakes and Temsah Lake. Egypt J Aquat Res 32(1):198-219

Rajagopal T, Thangamani A, Archunan G (2010) Comparison of physico-chemical parameters and phytoplankton species diversity of two perennial ponds in Sattur area, Tamil Nadu. J Environ Biol 31(5):787-794

Ramanathan N, Padmavathy P, Francis T, Athithian S, Selvaranjitham N (2005) Manual on polyculture of tiger shrimp and carps in freshwater. Tamil Nadu Veterinary and Animal Sciences University, Fisheries College and Research Institute, Thothukudi, pp 1-161

Saravanakumar A, Rajkumar M, Sesh Serebiah J, Thivakaram GA (2008) Seasonal variations in physico-chemical characteristics of water, sediment and soil texture in arid zone mangroves of Kachchh-Gujarat. J Environ Biol 29:725-732

Shannon CE, Weaver W (1963) The mathematical theory of communications. University Illinois, Urbana, p 117

Strickland JDH, Parsons TR (1968) A practical handbook of seawater analysis. Bull Fish Res Ed 167:311

Suski CD, Killen S, Keiffer JD, Tufts BL (2006) The influence of environmental temperature and oxygen concentration on the recovery of largemouth bass from exercise: implications for live-release angling tournaments. J Fish Biol 68:120-136

Suthers IM, Rissik D (2009) Plankton: a guide to their ecology and monitoring for water quality. CSIRO Publishing, Collingwood

Taofikat Adesalu (2012) Effects of physico-chemical parameters on phytoplankton of a Tidal Creek, Lagos, Nigeria. J Environ Ecol, 3(1):2157-6092. www.macrothink.org/jee118

Touliabah H, Taylor WD (2004) The phytoplankton of Great Bitter Lake, Egypt, including the impacts of nutrient-laden and heated effluents. Afr J Aquat Sci 29(2):259-264

Utermöhl H (1958) Zur Vervollkömmung der quantitative Phytoplankton-Methodik. Mitteilungen internationale Vereinigung für theoretische und angewandte Limnologie 9:1-38 